\title{
QUALIFICATION AND LIFE TESTING OF LI-ION VES16 BATTERIES
}

\author{
Stéphane Remy $^{(1)}$, Serge Lawson ${ }^{(1)}$, Stéphane Lefeuvre $^{(1)}$, Edouard Mosset $^{(1)}$, Maria Nestoridi $^{(2)}$ \\ (1) Saft, Defense \& Space Division, BP 1039, 86060 Poitiers - France, \\ (2) ESA/ESTEC, Keplerlaan 1, Postbox 299, 2200 AG Noordwijk - The Netherlands,
}

\section{stephane.remv@saftbatteries.com ; serge.lawson@saftbatteries.com ; stephane.lefeuvre@saftbatteries.com; \\ edouard.mosset@saftbatteries.com; Maria.Nestoridi@esa.int}

\begin{abstract}
In the frame of an ESA GSTP 5.2 activity (contract 4000105105), the qualification and life testing of a Saft range of Li-ion batteries based on VES16 cells and theirs autonomous simplified balancing system (SBS) has been carried out. In this abstract the development, qualification plan and successful results from all various tests conducted on the VES16 qualification battery modules are synthetized.
\end{abstract}

Up to the present time, Saft batteries have been mainly utilizing for space applications high capacity cells, like the 45 Ah VES180 and the 35 Ah VES140 cells, targeting predominantly space missions in Geostationary Earth Orbit (GEO). However following the qualification and commercialization of the Saft 4.5 Ah VES16 cell in October 2011 [1] \& [2], Saft has been developing and qualifying in the frame of this ESA GSTP 5.2 contract, VES 16 batteries for space missions, targeting both GEO and Low Earth Orbit (LEO) satellite missions. The electrochemistry of the VES16 cells used for the battery modules under the ESA qualification program is not novel. For VES16 cells, the Saft knowhow from large capacity space cells used for space applications, since SMART 1 mission in 2003, has been tailored for a cell with smaller capacity in order to facilitate the modular philosophy that has been deployed in this battery range.

\section{BATTERY MODULES DESIGN}

The VES16 battery design is based on standard building packs of different voltages, capacities and mechanical arrangements, in order to address most of the present and future space missions' needs.

The GSTP-5 tested VES16 battery designs are characterized by modularity, thus enhancing customization capabilities as per mission requirements and minimizing the number of relevant deltaqualification activities required for individual space missions.

VES16 battery range, proposed by Saft, adopts a S-P configuration, since cells are connected in series (S) to form a string and strings were connected in parallel $(\mathrm{P})$ to form a battery pack. The latter can individually form a battery module or a number of packs can be connected in parallel in order to form battery modules depending on capacity requirements.
The Saft VES16 battery line offers batteries ranging from 6 to $10 \mathrm{~S}$ and 4 to $8 \mathrm{P}$ configurations (Figure 1). This range includes a single deck also called "flat" (Figure 2) and a double deck (Figure 3) design aiming to fit any satellite accommodation. The aim of this qualification is not to test all the relevant modules but to test a number of representative ones for space applications, which have been called QM1 (2x10S8P), QM2 (10S5P) and QM3 (8S4P) detailed later in this document.

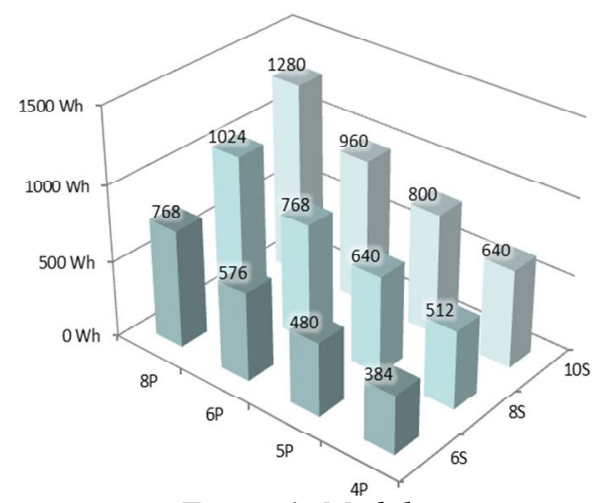

Figure 1: Modules energy range

from $384 \mathrm{Wh}$ to $1280 \mathrm{Wh}(\mathrm{EOCV}=4.1 \mathrm{~V}$ per cell)

The range can be extended to higher voltages configurations by simply increasing the number of cells in series configuration. Indicatively, an $11 \mathrm{~S}$ or $12 \mathrm{~S}$ case can be derived from the $10 \mathrm{~S}$ case by a simple homothetic arrangement.

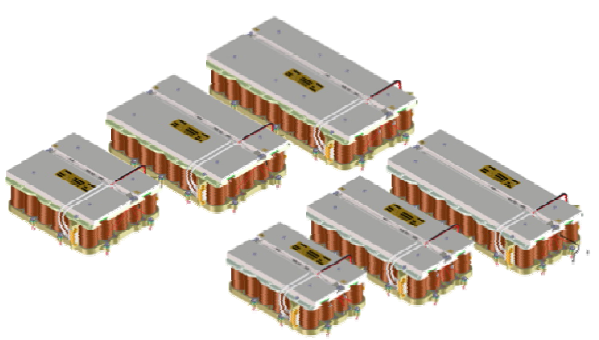

Figure 2: Single deck modules family 


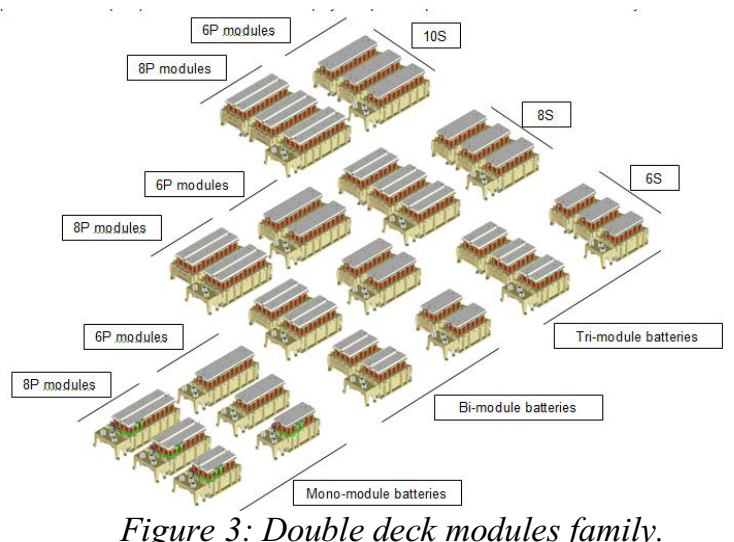

The single deck battery module is an arrangement of cells, glued by resin, between a baseplate and a top plate. Connection to the cell can is made with tabs to the cell case, for the cathode, and to the cell top cap, for the anode. All strings of cells are parallel connected by bus bars. On the terminals of each individual cell a balancing system is implemented, called simplified balancing system (SBS). The principle of this balancing electronics system is based on cell current consumption above a given voltage threshold U0 (Figure 4). The system is fully autonomous and requires neither command nor telemetry. To achieve this balancing function, the SBS architecture is based on a simple circuitry which core component is a micro shunt. This micro shunt component quality level, selected by Saft in order to optimize SBS function, is QML-Q (Class 2 component with specific additional upgrade tests and characterization) as baseline. But the same component is qualified in class 1 (QML-V) and fully interchangeable.

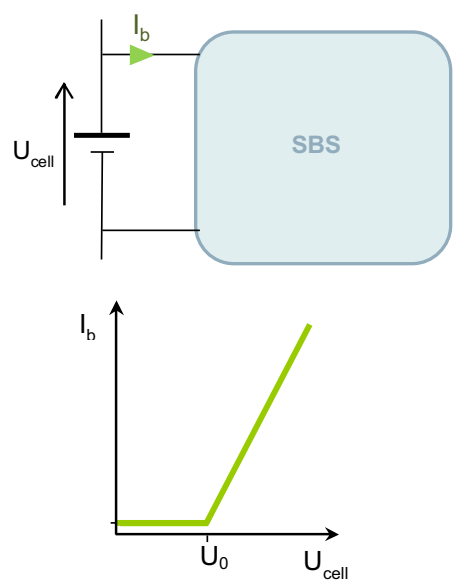

Figure 4: SBS principle

The battery module can be customised to include the required type and number of thermal sensors, heaters and monitoring connectors, even thermostats if needed. The connectors can be rectangular or circular, redundant or not, with separated or mixed polarities, as specified by Battery General Design and Interface Requirements. It is noticeable that the individual cell voltages are accessible on ground for any maintenance or health status check, by dedicated ground connectors, until the last days prior to launch.

The double-deck battery design is exactly the same as the single deck. The main principle is that the baseplate is shared between the two decks, so that the cells are glued on both sides of the baseplate. Therefore, the heart of the modules remains unchanged for all the VES16 batteries range.

\section{2}

\section{DEVELOPMENT OF VES16 BATTERIES}

This section describes the development and the design $\&$ analysis results at cell, SBS and battery level. The development plan is based on three main steps; the VES16 qualification plan, the SBS electronics qualification plan and the battery range design.

The design of the modules was justified mainly by the electrical, electronical, thermal and mechanical analyses.

In the frame of the GSTP-5.2 qualification Tests campaign, Saft completed these analyses, by detailed qualification tests results.

\subsection{Design main justifications}

Detailed analyses have been conducted for single and double deck modules, for LEO and GEO cases.

These analyses have demonstrated that the battery can sustain the various stresses generated by space environment, especially, the space missions' specific electrical, electronical, thermal and mechanical environmental requirements.

Hereafter, the main findings from the thermal, mechanical, reliability and radiation analyses are presented.

As a summary of thermal analysis, all the battery parts (cells, electronic components and wiring) remain within their derated values, (rated values in failed cases) with margins, for all 9 cases studied for single and double deck batteries.

The gradients within a string or within a module remain lower than $4^{\circ} \mathrm{C}$, in all cases, as can be seen in Figure 7 .

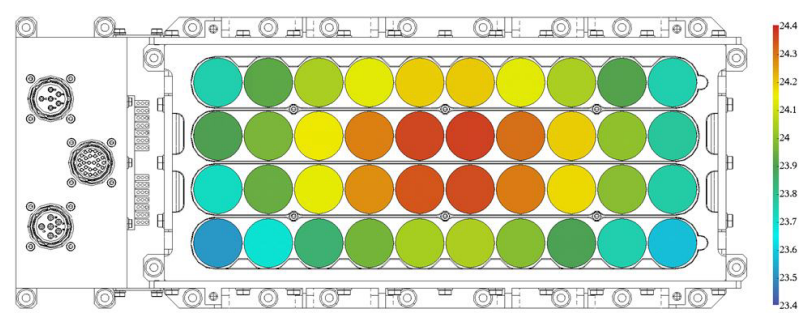

Figure 5: Illustration LEO case, BoL@20 $9{ }^{\circ}$ 


\section{Battery modules mechanical behaviour:}

The modal analyses provided the natural frequencies of the structures and cells, which were the following:

- Above $400 \mathrm{~Hz}$ for the 10S8P module (QM1),

- Above $1000 \mathrm{~Hz}$ for the 10S5P module (QM2),

- Above $1090 \mathrm{~Hz}$ for the 8S4P module (QM3),

The mechanical analysis showed that for random loads the structure and cells MOSyield are all positive and the minimum is locally for the cells' structure when the battery is loaded along the vertical-axis.

\section{Reliability}

The reliability analysis concluded that for a 12.5 years LEO mission, taking into account the loss of one string, a probability of success is $99,86 \%$ and $99,99 \%$ for the QM1 battery (2x10S8P) and the QM2 battery (10S5P) respectively.

\section{Radiations:}

The VES16 cell can withstand radiation levels up to 5 MRads. The only battery item that can be sensitive to radiations, is the SBS core component.

The component has been qualified, by ELDRS test, with 36 rad.s-1 rate, at $140 \mathrm{krads}$ total dose.

In order to verify that this SBS core component will not be a limitation for the VES16 battery in orbit life, radiation and shielding analyses of the VES16 battery design studies have been carried out for the QM1 module.

Four mission cases have been considered:

- 12 years LEO mission at $700 \mathrm{~km}$;

- 12 years LEO mission at $1200 \mathrm{~km}$;

- 10 years MEO mission at $23616 \mathrm{~km}$;

- 15 years GEO mission at $35870 \mathrm{~km}$.

\section{Electronics:}

The electronics SBS system is fully autonomous and requires neither command, nor telemetries. This system was developed with CNES support, to address all relevant space design requirements and issues.

The battery system has been modeled, using P-spice, following ESA experts approach guidelines, to assess its behaviour in worst case conditions @ EOL. [7]

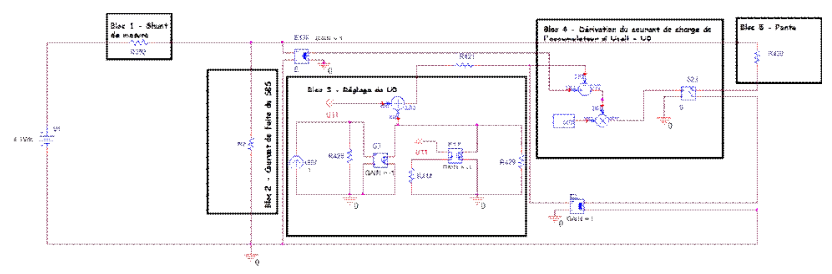

Figure 6: SBS model diagram

The model has been correlated with real battery balancing test, achieved on the QM3 battery.

\section{GSTP-5 QUALIFICATION CAMPAIGN}

In the frame of the ESA GSTP 5.2 Qualification activity, three different batteries have been selected to be submitted to the qualification campaigns.

Those include two different single deck "flat" modules; a 8S4P (called QM3, shown in Figure 7) a 10S5P module (called QM2, shown in Figure 8) and also a 2x10S8P double deck module (called QM1, shown in Figure 9).

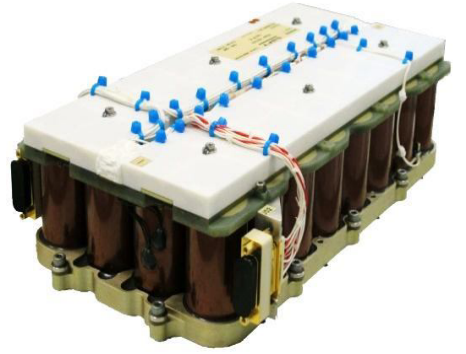

Figure 7: QM3 - 8S4P VES16 module

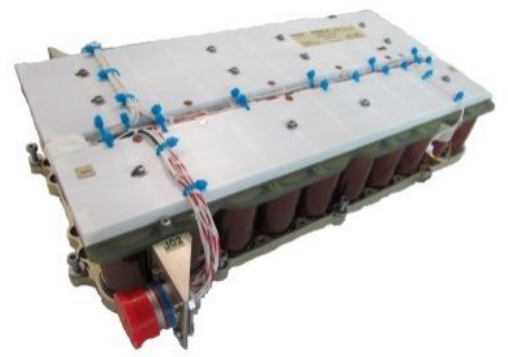

Figure 8: QM2 - 10S5P VES16 module

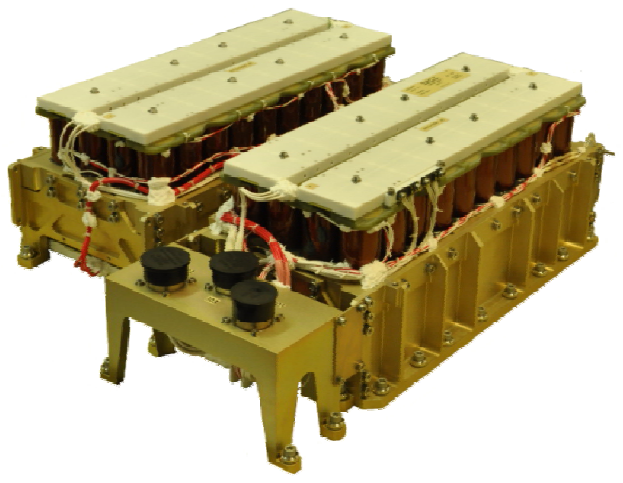

Figure 9: QM1 - 10S16P VES16 battery 
In Table 1, the Qualification test matrix for the three modules is presented.

\begin{tabular}{|c|c|c|c|}
\hline $\begin{array}{l}\text { GSTP-5.2 QUALIFICATION } \\
\text { PROGRAM }\end{array}$ & $\begin{array}{c}\text { QM1 } \\
\text { 2x10S8P } \\
\text { VES16 }\end{array}$ & $\begin{array}{c}\text { QM2 } \\
\text { 10S5P } \\
\text { VES16 }\end{array}$ & $\begin{array}{c}\text { QM3 } \\
\text { 8S4P } \\
\text { VES16 }\end{array}$ \\
\hline \multicolumn{4}{|l|}{ CHARACTERIZATION TESTS } \\
\hline Conformity check & $\mathrm{X}$ & $\mathrm{X}$ & $\mathrm{X}$ \\
\hline Functional tests and inspections: & $\mathrm{X}$ & $\mathrm{x}$ & $\mathrm{X}$ \\
\hline Initial charge retention & $\mathrm{X}$ & $\mathrm{x}$ & $\mathrm{X}$ \\
\hline $\begin{array}{l}\text { Stored energy measurements at } \\
\text { various discharge temperatures and } \\
\text { discharge currents }\end{array}$ & & $x$ & \\
\hline $\begin{array}{l}\text { Self-discharge measurement in } \\
\text { several conditions (SOC, Temp.) }\end{array}$ & & & $\mathrm{x}$ \\
\hline $\begin{array}{l}\text { Internal Resistance measurement at } \\
0 \% \text { DOD , } 20 \% \text { DOD and } 60 \% \text { DOD }\end{array}$ & & $x$ & \\
\hline Charge retention $(72$ hours, @20²) & $\mathrm{X}$ & $\mathrm{x}$ & $\mathrm{x}$ \\
\hline Impedance at $0 \% \mathrm{DOD}, 50 \% \mathrm{DOD}$ & & $\mathrm{x}$ & $\mathrm{x}$ \\
\hline Balancing efficiency Tests & $\mathrm{X}$ & $\mathrm{x}$ & $\mathrm{X}$ \\
\hline \multicolumn{4}{|l|}{ ENVIRONMENTAL TESTS } \\
\hline $\begin{array}{l}\text { Sine vibrations ( } 3 \text { axes) including } \\
\text { resonance frequencies search before } \\
\text { and after. }\end{array}$ & $\mathrm{X}$ & $x$ & $x$ \\
\hline $\begin{array}{l}\text { Random vibrations ( } 3 \text { axes) including } \\
\text { resonance frequencies search before } \\
\text { and after. }\end{array}$ & $\mathrm{x}$ & $\mathrm{x}$ & $\mathrm{x}$ \\
\hline Charge retention $\left(72\right.$ hours, $\left.@ 20^{\circ} \mathrm{C}\right)$ & $\mathrm{x}$ & $x$ & $\mathrm{X}$ \\
\hline $\begin{array}{l}\text { Stored energy measurements } @ 20^{\circ} \mathrm{C} \\
\text { with IR measured at } 20 \% \& 60 \% \\
\text { DOD }\end{array}$ & $\mathrm{X}$ & $x$ & $\mathrm{X}$ \\
\hline Shocks tests (3 impacts per axes) & $\mathrm{X}$ & $\mathrm{X}$ & \\
\hline Charge retention (72 hours, @ $\left.20^{\circ} \mathrm{C}\right)$ & $\mathrm{x}$ & $x$ & \\
\hline $\begin{array}{l}\text { Stored energy measurements } @ 20^{\circ} \mathrm{C} \\
\text { with IR measured at } 20 \% \& 60 \% \\
\text { DOD }\end{array}$ & $x$ & $x$ & \\
\hline CORONA TEST & $\mathrm{x}$ & $\mathrm{x}$ & \\
\hline $\begin{array}{l}\text { Thermal cycling in vacuum } \\
\text { conditions }\end{array}$ & $\mathrm{X}$ & $x$ & \\
\hline Leak Test & $\mathrm{x}$ & $\mathrm{x}$ & \\
\hline Magnetic Moment Measurements & & $x$ & \\
\hline EMC test & & $x$ & \\
\hline Impedance Measurements & $\mathrm{x}$ & $x$ & $x$ \\
\hline Charge retention (72 hours, @ $\left.20^{\circ} \mathrm{C}\right)$ & $\mathrm{X}$ & $\mathrm{x}$ & \\
\hline $\begin{array}{l}\text { Stored energy measurements } @ 20^{\circ} \mathrm{C} \\
\text { with IR measured at } 20 \% \& 60 \% \\
\text { DOD }\end{array}$ & $\mathrm{X}$ & $\mathrm{x}$ & \\
\hline Conformity check & $\mathrm{x}$ & $\mathrm{x}$ & $\mathrm{X}$ \\
\hline \multicolumn{4}{|l|}{ LIFE TESTS } \\
\hline $\begin{array}{l}\text { LEO Life tests } 30 \% \mathrm{DOD}, @ 20^{\circ} \mathrm{C} \text {, in } \\
\text { real time }\end{array}$ & & & $x$ \\
\hline
\end{tabular}

Table 1: Qualification Test Matrix

As planned and foreseen, all three modules were submitted to characterization and environmental tests. QM3 battery is presently submitted to LEO life tests.

\subsection{Characterisation Tests}

Characterisation tests have been successfully completed for the three batteries QM1 (10S16P VES16), QM2 (10S5P VES16) and QM3 (8S4P VES16). Main results are presented hereafter.

\subsubsection{Characterisation Tests on QM1}

In Figure 10, the effect of discharge current while keeping a fixed charge rate $\mathrm{C} / 10$ is shown.

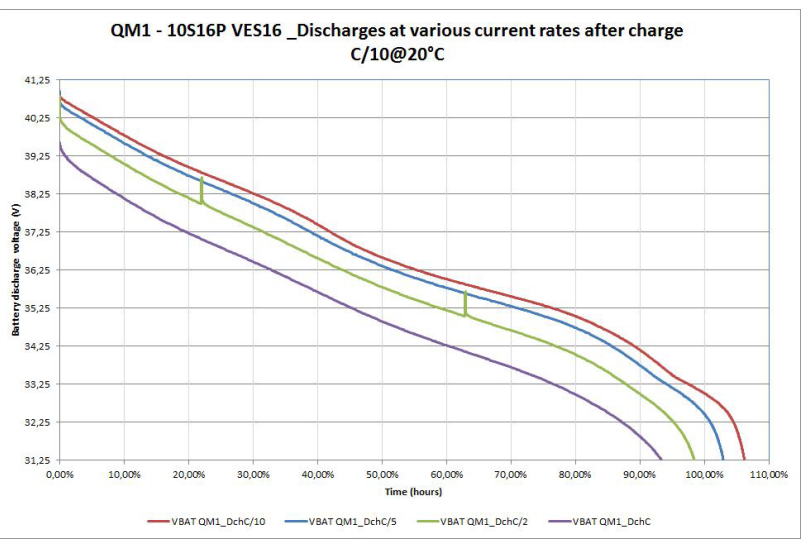

Figure 10: Discharge voltages vs Discharge Currents after chargeC/10@20C.

In Figure 11, the battery charge and discharge voltage profiles of each cell are shown, allowing assessing the cells balancing inside the battery, thanks to AIT connectors, set on balancing (SBS) boards.

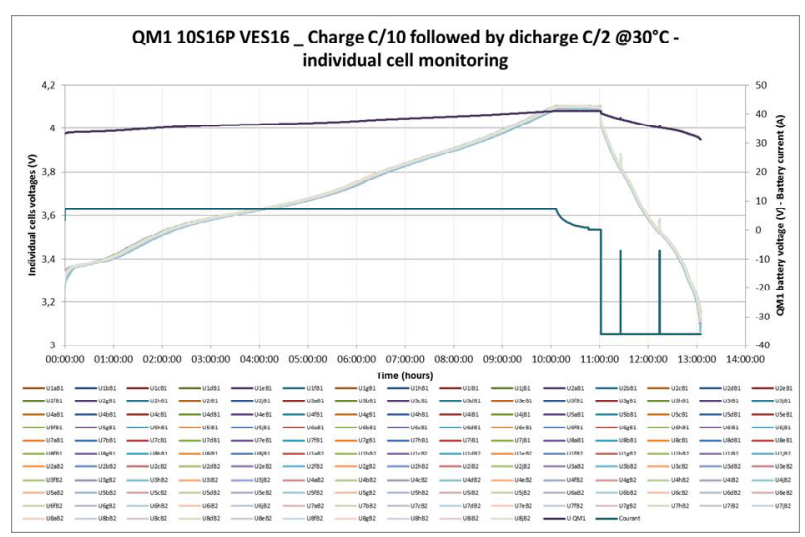

Figure 11: Battery Charge \& Discharge@30 $3{ }^{\circ} \mathrm{C}$ continuous monitoring of individual cells

All results obtained during electrical characterization of the QM1 battery were in line with expectations.

\subsubsection{Characterization Tests on QM2 - 10S5P VES16}

The main objective of the QM2 battery characterization test campaign was to characterise the battery at different charge / discharge rates and temperatures. The aim was to ease construction of a battery performance detailed meshing, for future batteries sizing, including not only cell, but also battery architecture contribution (parallel and series connections in particular). 


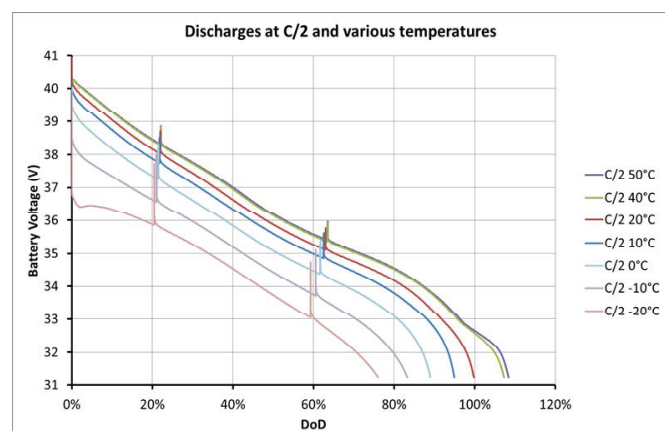

Figure 12: Battery Discharge@C/2 vs Temperature

The characterization campaign has been completed successfully, for QM2 battery, and the battery has been authorised to pass through the environmental tests campaign as described in the following paragraphs.

\subsubsection{Characterisation Tests on QM3 - 8S4P VES16}

Balancing system capability demonstration was performed, by introducing a $50 \mathrm{mV}$ voltage deviation/unbalance between a single cell and the rest of the cells, in the module. The modules were then submitted to LEO (20\% DoD), and GEO (70\% DoD max), cycling in order to check the duration or number of charge / discharge cycles needed to re-equilibrate / balance the string voltages.

The $50 \mathrm{mV}$ value, between average cell and unbalanced cell, was chosen since this value corresponds typically to the relevant unbalance obtained after 6 months of storage period. In Figure 13 and Figure 14, it is shown that the initial unbalance is recovered after less than 30 days in LEO, and less than 15 eclipse days in GEO cycling.

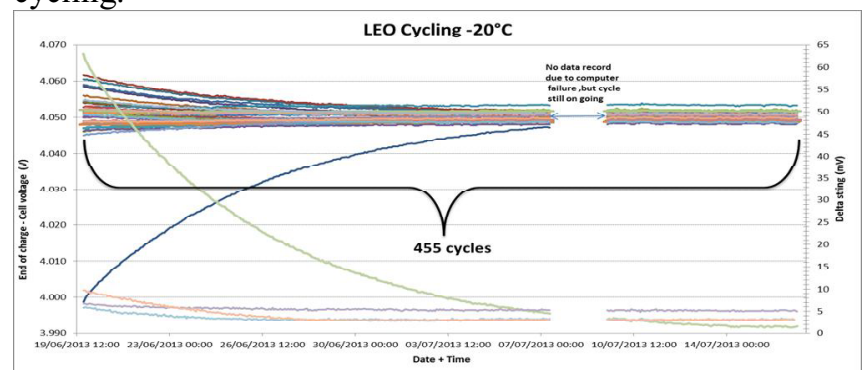

Figure 13: QM3 Battery voltage spread recovery after unbalance in $L E O$

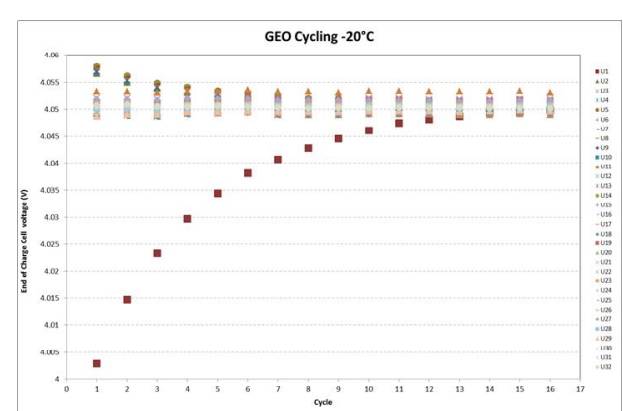

Figure 14: QM3 Battery cells' voltages spread recovery after unbalance during GEO cycles.
Once electrical behaviour of the three batteries QM1, QM2 and QM3 was assessed, by the characterization tests completion, authorization was granted to continue the qualification tests sequences with thermal, mechanical and other Space missions' environments.

\section{2 environmental Test Results}

\subsubsection{Environmental Tests on QM1 module}

The QM1 module was submitted to environmental tests, consisting in:

- Mechanical vibrations;

- Shocks tests and;

- Thermal vacuum cycles

\subsubsection{QM1 - Mechanical vibrations}

QM1 battery was tested in following mechanical vibrations:

- $\quad$ Sine vibrations $(24 g)$

- Random vibrations (12.6 Grms).

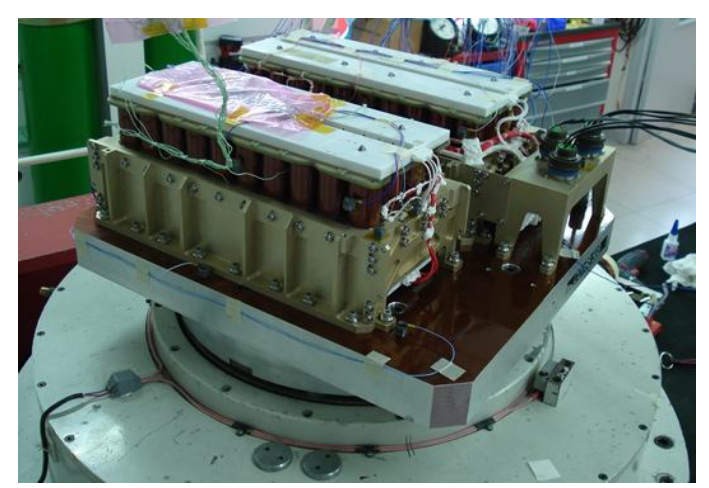

Figure 15: QM1 during shock tests.

\subsubsection{QM1 10S16P VES16 - Mechanical Shocks}

QM1 battery was tested in mechanical shocks (hammer test):

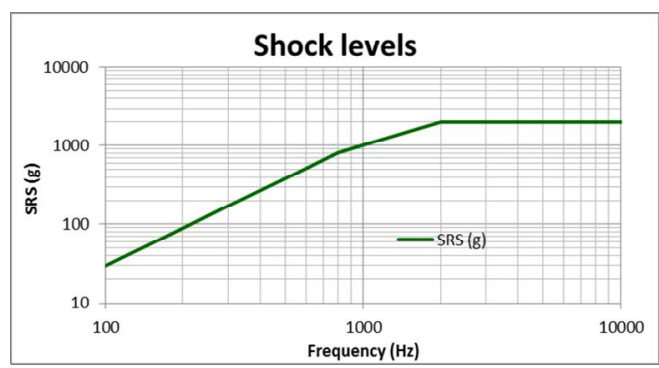




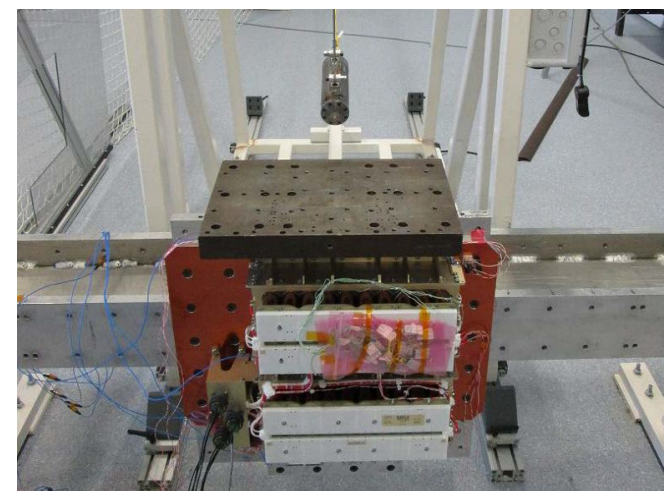

Figure 16: QM1 during shock tests.

Three impacts were realized per axis, with battery discharges and battery voltage noise measurements, during shocks.

In conclusion, the QM1 environmental mechanical sequence has been performed successfully.

\subsubsection{QM1 - Thermal Vacuum Test}

The QM1 battery was submitted to thermal environmental tests, in thermal vacuum chamber, in order to be as close as possible to VES16 batteries mission operating conditions.

\begin{tabular}{|c|c|c|}
\hline PHASE & $\begin{array}{c}\text { BATTERY POWER } \\
\text { CHARGE/DISCHARGE }\end{array}$ & $\begin{array}{l}\text { MOUNTIN } \\
\text { G PLANE } \\
\mathrm{T}^{\circ} \mathrm{C}\end{array}$ \\
\hline CORONA TEST & OPEN CIRCUIT & $20^{\circ} \mathrm{C}$ \\
\hline $\begin{array}{l}\text { CONDUCTANCE } \\
\text { MEASUREMENT } \\
\text { AT STEADY } \\
\text { STATE } \\
\end{array}$ & OPEN CIRCUIT & $\begin{array}{l}0^{\circ} \mathrm{C} \\
10^{\circ} \mathrm{C} \\
40^{\circ} \mathrm{C}\end{array}$ \\
\hline $\begin{array}{c}\text { HEATERS } \\
\text { FUNCTIONNAL } \\
\text { TESTS } \\
\end{array}$ & OPEN CIRCUIT & $0^{\circ} \mathrm{C}$ \\
\hline CAPACITY TEST 1 & $\begin{array}{c}\text { I charge }=\mathrm{C} / 10, \text { until EocV }=41 \mathrm{~V} . \\
\mathrm{EOCV}=4.1 \mathrm{~V} / \text { cell } \\
\text { Discharge at } \mathrm{I}=\mathrm{C} / 2\end{array}$ & $20^{\circ} \mathrm{C}$ \\
\hline CAPACITY TEST 2 & $\begin{array}{c}\text { I charge }=\mathrm{C} / 10 \text {, until EocV }=41 \mathrm{~V} . \\
\mathrm{EOCV}=4.1 \mathrm{~V} / \text { cell } \\
\text { Discharge at } \mathrm{I}=\mathrm{C} / 2\end{array}$ & $40^{\circ} \mathrm{C}$ \\
\hline CAPACITY TEST 3 & $\begin{array}{c}\text { I charge }=\mathrm{C} / 30 \text {, until EocV }=41 \mathrm{~V} . \\
\mathrm{EOCV}=4.1 \mathrm{~V} / \mathrm{cell} \\
\text { Discharge at } \mathrm{I}=\mathrm{C} / 2\end{array}$ & $0^{\circ} \mathrm{C}$ \\
\hline CAPACITY TEST 4 & $\begin{array}{c}\text { I charge }=\mathrm{C} / 10, \text { until EocV }=41 \mathrm{~V} . \\
\mathrm{EOCV}=4.1 \mathrm{~V} / \mathrm{cell}, \\
\text { Discharge at } \mathrm{I}=\mathrm{C} / 2\end{array}$ & $10^{\circ} \mathrm{C}$ \\
\hline CAPACITY TEST 5 & $\begin{array}{c}\text { I charge }=\mathrm{C} / 10, \text { until EocV }=41 \mathrm{~V} . \\
\mathrm{EOCV}=4.1 \mathrm{~V} / \text { cell, } \\
\text { Discharge at } \mathrm{I}=\mathrm{C} / 2\end{array}$ & $30^{\circ} \mathrm{C}$ \\
\hline $\begin{array}{l}\text { LEO CYCLE (2 } \\
\text { cycles per temp.) }\end{array}$ & $\begin{array}{c}\text { I charge }=\mathrm{C} / 3 \text { during } 65 \mathrm{~min} \text {, until } \\
\text { EocV }=40.5 \mathrm{~V} . \\
\text { I discharge }=\mathrm{C} / 1.95 \text { during } 35 \mathrm{mn}\end{array}$ & $\begin{array}{c}+10^{\circ} \mathrm{C} \\
30^{\circ} \mathrm{C}\end{array}$ \\
\hline $\begin{array}{l}\text { GEO CYCLE (2 } \\
\text { cycles per temp.) }\end{array}$ & $\begin{array}{c}\text { I charge }=\mathrm{C} / 10 \text { during } 1368 \mathrm{~min} \text {, } \\
\text { until } \mathrm{EocV}=40.5 \mathrm{~V} . \\
\text { I discharge }=\mathrm{C} / 1.5 \text { during } 72 \mathrm{mn}\end{array}$ & $\begin{array}{l}+10^{\circ} \mathrm{C} \\
+30{ }^{\circ} \mathrm{C}\end{array}$ \\
\hline $\begin{array}{l}\text { PULSES TEST } \\
\text { (repeated } 3 \text { times) }\end{array}$ & $\begin{array}{l}1 \text { pulse of } 1.9 \mathrm{C} \text { for } 5 \text { minutes } \\
4 \text { pulses of } 1.9 \mathrm{C} \text { for } 75 \text { seconds }\end{array}$ & $+10{ }^{\circ} \mathrm{C}$ \\
\hline $\begin{array}{l}\text { Thermal vacuum } \\
\text { Cycling ( } 8 \text { cycles) }\end{array}$ & OPEN CIRCUIT & $\begin{array}{l}-5^{\circ} \mathrm{C} \\
45^{\circ} \mathrm{C}\end{array}$ \\
\hline
\end{tabular}

Table 2: Thermal vacuum tests sequence

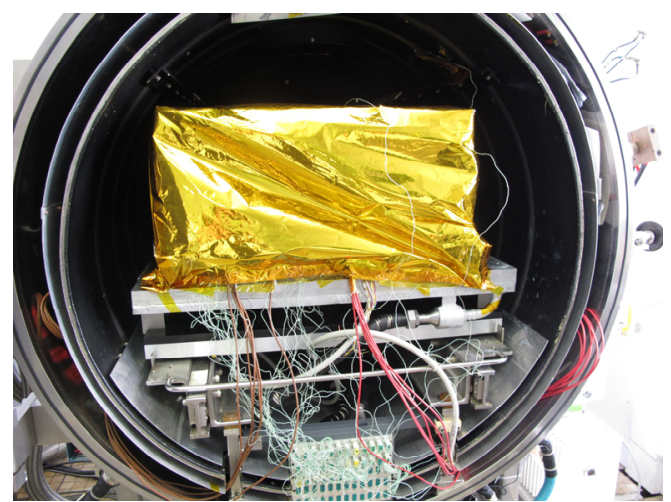

Figure 17: QM1 prepared for thermal vacuum tests.

\subsubsection{QM1 10S16P VES16 - Leak Tests}

Battery leak rate was measured to 2.8 10-7 mbar.1/s, compliant to the leak rate criterion.

QM1 battery successfully passed all the Qualification tests Sequence.

\subsubsection{QM2 10S5P VES16 - Environmental Tests.}

The QM2 module was submitted to environmental tests, consisting in:

- Mechanical vibrations;

- Shocks tests and;

- Thermal vacuum cycles

\subsubsection{QM2 10S5P VES16 - Mechanical vibrations}

QM2 battery was tested in vibrations:

- $\quad$ Sine vibrations (24 g)

- $\quad$ Random vibrations (14.8 Grms)

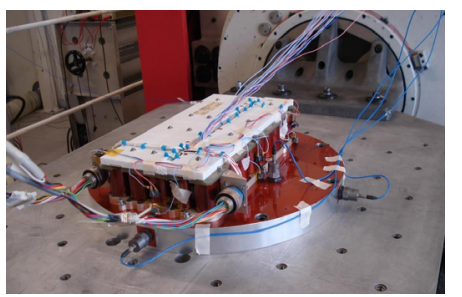

Figure 18: QM2 on vibration shaker.

The first resonance frequencies measured, in module width axis, were above $1000 \mathrm{~Hz}$, which correlates well with the relevant simulations. 


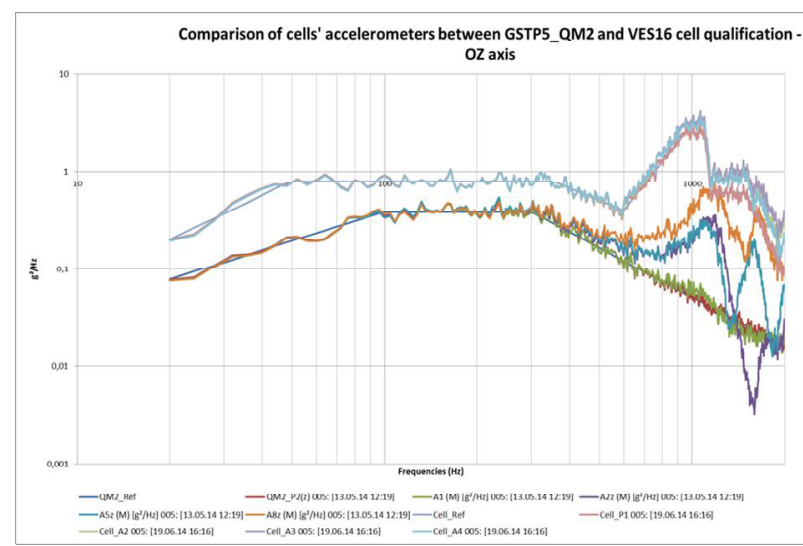

Figure 19: QM2 cells' accelerometers comparison with VES16 cell qualification.

\subsubsection{QM2 10S5P VES16 - Mechanical Shocks}

QM2 battery was tested in mechanical shocks (hammer test) according to following levels:
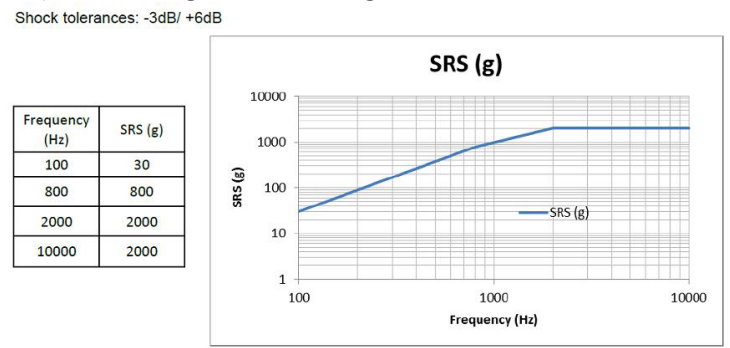

Figure 20: QM2 shocks tests levels.

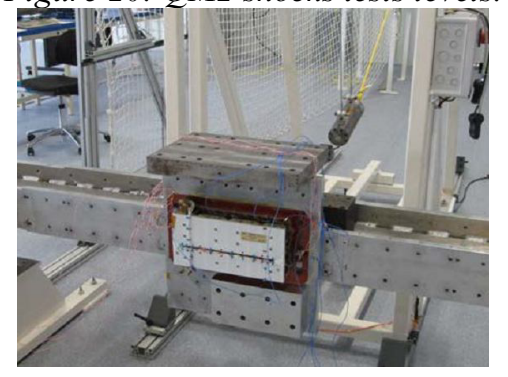

Figure 21: QM2 during shocks tests.

Three impacts were realized, per axis, with battery discharges and battery voltage noise measurements during shocks.

In conclusion, the QM2 environmental mechanical sequence has been passed successfully.

\subsubsection{QM2 10S5P VES16 - Thermal Vacuum Test}

The QM2 battery was submitted to thermal environmental tests in thermal vacuum chamber to be as close as possible to VES16 battery mission operating conditions.

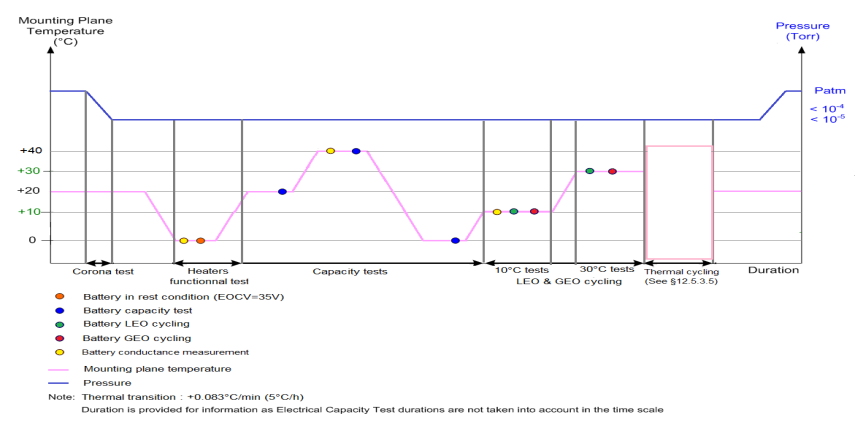

Figure 22: QM2 Thermal vacuum tests sequence

\subsubsection{QM2 10S5P VES16 - EMC Tests}

Following mechanical and thermal environments tests, on this QM2 10S5P VES16 battery, we seize the opportunity of this QM2 battery availability and qualification sequence to characterize battery magnetic moment and battery Electro-Magnetic Compatibility through tests and measurements, in various configurations:

- Magnetic Moment measurement sequence was in line with ECSS-E-ST-20-07C and battery operating conditions described

Stray field: battery operating, measurement on the six semi-axes, at the reference distances. Characteristics of the battery charge/ discharge rates are:

$$
\begin{array}{ll}
\text { * Ich }=\mathrm{C} / 10, \mathrm{Idch}=\mathrm{C} / 1.5 \text { (GEO case) } \\
\text { \% Ich }=\mathrm{C} / 3, \mathrm{Idch}=\mathrm{C} / 2.5 \text { (LEO case) } \\
\text { Ich }=\mathrm{C} / 3, \mathrm{Idch}=\mathrm{C} \text { (radar peak case) }
\end{array}
$$

- EMC test sequence was in line with ECSS-EST-20-07C and cover cases in table:

\begin{tabular}{|c|c|}
\hline Topic & Title \\
\hline Characterization & System characterization \\
\hline \multirow{3}{*}{ CS } & $\begin{array}{c}\text { CS, power leads, differential mode, 30 Hz to } \\
50 \mathrm{MHz}\end{array}$ \\
\cline { 2 - 2 } & $\begin{array}{c}\text { CS, power \& signal leads, common mode, } 50 \\
\mathrm{kHz} \text { to } 100 \mathrm{MHz}\end{array}$ \\
\cline { 2 - 2 } & CS, power leads, short spike transients \\
\hline \multirow{2}{*}{ RS } & RS, electric field, 30 MHz to 40 $\mathrm{GHz}$ \\
\hline \multirow{2}{*}{ Characterization } & $\begin{array}{c}\text { Susceptibility to electrostatic discharges - } \\
\text { Conducted }\end{array}$ \\
\cline { 2 - 2 } & $\begin{array}{c}\text { Susceptibility to electrostatic discharges- } \\
\text { Radiated }\end{array}$ \\
\hline
\end{tabular}

Table 3: QM2-10S5P VES16 EMC Test sequence

\subsubsection{QM2 10S5P VES16 - Final Tests}

The leak rate and final functional tests and conformity inspections results allow concluding that the QM2 battery successfully passed all the environmental tests Sequence.

\subsubsection{Environmental Tests on QM3 module}

As part of the environmental tests, the QM3 module has been submitted to sine vibration ( $24 \mathrm{~g}$ ) and random 
vibrations (11 Grms in lateral axis, and $17 \mathrm{Grms}$ on vertical axis) at qualification levels.

The resonance frequencies were above $1100 \mathrm{~Hz}$, on all axes, which correlate well with the relevant simulations.

In short, the QM3 environmental mechanical sequence has been performed successfully, as shown by battery impedance and final functional tests results.

\subsection{LEO Life Testing on QM3 module}

LEO life tests have been initiated with the QM3 battery, at the following conditions:

- $\quad$ Real Time LEO, $20^{\circ} \mathrm{C}$

- $\mathrm{DoD}=30 \%$

- Charge $\mathrm{C} / 3$ during 65 minutes up to $4.05 \mathrm{~V}$ per cell (or $\mathrm{I}<80 \mathrm{~mA}$ )

- Discharge $\mathrm{C} / 2$ during 35 minutes.

The above conditions were selected to be stringent enough to fit with mostly needed life test qualification conditions; but also to be comparable with existing Saft cell level running life tests.

Relevant Saft Life test, at cell level, is referenced E107: 20000 cycles have been achieved on 3 cells and 18000 cycles achieved on 3 other cells.

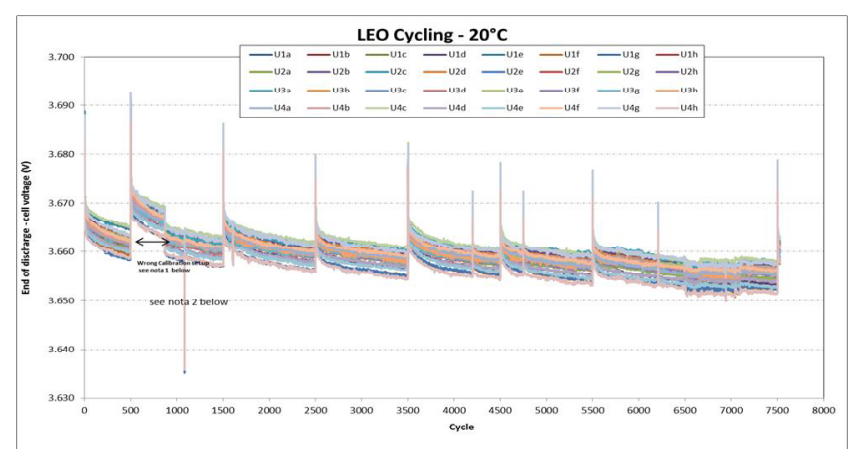

Figure 23: QM3 LEO life test after 7500 cycles (EoDV)

In Figure 23, the EoDVs for the 24 cells of QM3 battery during its LEO life test are shown. Despite the fact that this is only the beginning of the life test, the results obtained to this moment are satisfactory. As it is shown in Figure 30, there is only a $7.5 \mathrm{mV}$ deviation between all cells at $3.65 \mathrm{~V}$, at the end of each discharge.

The current life test is of great interest for potential future LEO applications since the QM3 battery is fully representative of a complete flight system.

\section{CONCLUSION}

All characterisation and environmental tests carried out on those 3 qualification batteries have been successfully carried out, which allow providing a complete battery designs ranges, qualified to stringent environments and available for the space community.

This activity, supervised by ESA, has greatly helped Saft to reinforce its battery design performances justification.

Today, more than 15 contracts, embedding VES16 batteries, have been awarded to Saft, by all European major primes and agencies both in LEO and GEO projects.

VES16 cells and batteries are cutting edge designed, multi-purpose missions and extended demanding needs, robust, modular, made for long life cycle with space mission required reliability.

\section{REFERENCES}

[1] D. Prévot, F. Vigier. "Saft VES16 Li-ion qualification synthesis report", Ref. S0115-12, May 2015.

[2] S. Remy, D. Prévot, D. Reulier, F. Vigier. "VES16 Li-ion cell for satellites", 9th ESPC Proceedings, Article 2103465, June. 2011.

[3] E. Mosset. "Active \& Autonomous Balancing System" 9th ESPC Proceedings, Article 2103452, June. 2011.

[4] S. Remy, E. Mosset, S; Lefeuvre, M. Nestoridi. "VES16 li-ion batteries range qualification" 10th ESPC Proceedings, April. 2014.

[5] M. Nestoridi, O. Mourra, E. Mosset, S. Lefeuvre, S. Remy "Effect of an induced cell soft-short at a VES16 battery" 10th ESPC Proceedings, April. 2014.

[6] VES16 battery range, GSTP-5 design, Final Data Package, ref. S3561-15

[7] S. Lefeuvre, A. Benkhalfia, E; Mosset, O. Mourra, M. Nestoridi "Battery simulation Tool" 11th ESPC Proceedings, Oct. 2016. 